\title{
A FRAMEWORK TO INVESTIGATE MONEY ATTITUDES AND MATERIALISM
}

\author{
Helen Duh: School of Business and Finance, University of the Western Cape \\ Miemie Struwig: Director School of Management Sciences, Nelson Mandela Metropolitan \\ University \\ Eileen Mazibuko: Department of Business Management,Nelson Mandela Metropolitan \\ University
}

\begin{abstract}
Purpose and/or objectives: This paper presents a framework to investigate money attitudes and materialistic values. The conceptualization of the framework is guided by a critical review of literature. The intention is to provide a framework that will be useful to examine how various childhood family experiences influence later-life consumption orientations.

Problem investigated: The differences in family resources represent one of the biggest distinctions between an intact and a disrupted family. The underlining question is whether children raised in disrupted families will experience lower levels of family resources (economic and emotional) and find the experience stressful. If so, will these experiences influence them to adopt conservative money attitudes and be less materialistic or will they symbolically value money and be more materialistic?
\end{abstract}

Design/methodology/approach: The development of a framework requires a critical review of secondary sources. The literature review is based on theories that provide an explanation of how childhood family experiences can affect the development of materialistic values and money attitudes. The secondary sources require careful scrutiny of journal articles, dissertations and essays in a number of libraries to provide more scholarly insight into the concepts and to assist in the conceptualisation of the framework.

Findings and/or implications: Four main theories were found useful in conceptualizing the framework. They are Ryan and Deci's (2000) self-determination theory, Maslow's (1943) human need theory, Wicklund and Gollwitzer's (1982) symbolic self-completion theory and the life course theory contextualized by Moschis (2007). However, in line with Moschis' (2007) realization, the perspectives of the life course theory were found to be multi-disciplinary, multi-theoretical and thus innovative .They would therefore form the main theoretical guide for the design of the framework.

Originality and/or value of the research: The paper provides a framework to investigate the moderating effect that money attitudes can have on how childhood family experiences influence later-life materialistic values. This proposed framework may form the building blocks for a number of empirical studies especially as the life course approach in studying consumption orientations is innovative and multidisciplinary.

Conclusion: The framework includes as independent variable, childhood family structure. Depended variables are perceived level of family resources, stress and materialistic values. Money attitudes are regarded as moderating variables.

Keywords: Childhood family experiences, Money attitudes, Materialistic values, Life course study,

\section{INTRODUCTION}

Although the importance of childhood experiences in shaping later-life behaviour had long been acknowledged (Ward, 1974), consumer researchers have only begun to assess the implications of childhood family experiences on consumption orientations. Rindfleisch, Burroughs and Dentton's (1997) study for example, is one of the first attempts to model childhood family disruption (in terms of divorce) and its impact on materialism and compulsive buying. Roberts, Manolis \& Tanner, (2006); Rindfleisch et al.(1997) and later other researchers such as Benmoyal-Bouzaglo \& Moschis (2009 and 2010); Roberts, Manolis \& Tanner (2003) and Roberts et al. (2006) adopted the life course approach and found that individuals who were reared in disrupted family structures scored higher in materialism and compulsive buying behaviour. This relationship can be mediated by family resources (economic and emotional support) and perceived stress from the disruptive events. 
For better understanding of the consumption outcomes of family disruptions Benmoyal-Bouzaglo and Moschis (2009) recommend that other psychological consequences (apart from stress) of family disruptions be incorporated into the life course model of consumption orientations. One psychological consequence which has not been examined within the life course model and that may moderate the extent to which adverse childhood family experiences affect materialism, is money attitudes. Depending on the various beliefs and meanings children reared in disrupted homes adopt about money, such as power/prestige, achievement, retention, security/conservative, and worry (Yamauchi \& Templer, 1982; Rose \& Orr, 2008), one would expect their tendency to develop materialistic values to be either fostered or deterred.

Furthermore, the development of materialistic values from family disruptions may vary for different age groups and cultural settings (Benmoyal-Bouzaglo \& Moschis, 2010). This study will thus use the life course approach to develop a framework that can be used to examine money attitudes and materialism and also assess the moderating role of money attitudes on the relationship between childhood family experiences and materialism. The background to the research will first be outlined after which a review of four theories useful in the conceptualization of the framework will be provided. The proposed framework is thereafter presented and its variables explained.

\section{BACKGROUND TO THE RESEARCH}

Materialism has become a lifestyle that appears to be an integral part of modern day living (Watson, 2003). Commonly viewed as an inescapable and undesirable aspects of consumer culture (Rindfleisch, et al, 1997) investigations into the factors that can be implicated for the growth of materialism is common. Most of the research on materialism explains how materialism correlates with some psychographic, demographic and economic variables (Watson, 2003). However, little is known of what causes or predicts materialism in the first place (Flouri, 1999). Particularly, relatively little is known of how childhood family experiences affect the development of materialistic values especially through various psychological processes.

Rindfleisch et al. (1997) postulate that children who experienced disruptive family events become materialistic because these events were stressful and could have impaired self-esteem. If low selfesteem can be engendered, would it not first affect money attitudes? Hanley and Wilheim (1992) for example, found that compulsive spenders hold symbolic attitudes (obsession and power/prestige) towards money, because they believe in its ability to enhance self-esteem. Looking at the diverse beliefs and feelings people hold about money (power/prestige, retention, security, achievement) and Gurney's (1988) claim that money attitudes begins in childhood, remains in adulthood, and influence later behaviours related to money, it will be necessary to assess the moderating role money attitudes play in the relationship between childhood family experiences and materialism within the life course model.

\section{LITERATURE OVERVIEW OF THEORIES TO CONCEPTUALISE THE FRAMEWORK}

A number of social sciences, family and social psychological theories provide explanations of how materialistic values and money attitudes can develop. Four of the theories considered useful in conceptualizing a possible framework are Ryan and Deci's (2000) self-determination theory, Maslow's (1943) human need theory, Wicklund and Gollwitzer's (1982) symbolic self-completion theory and the life course theory contextualized by Moschis (2007). Each of these theories provides useful insights into how materialistic values and money attitudes can develop. The perspectives of the life course theory Moschis (2007) advocates are multi-disciplinary, multi-theoretical and innovative. They will thus be the blueprint for the construction of the proposed framework. 


\section{The Self-determination Theory}

Ryan and Deci's (2000) self-determination theory posits that the way and degree to which children's growth (food and shelter) and psychological (love, emotional support, sense of belonging, esteem) needs are satisfied have important implications for the values they will later develop and adhere to. Drawing from this theory, Kasser, Koestner and Lekes (2002) suggest that individuals may become concerned with self-worth and consume on grounds of how others view them when the environment in which they grew up, blocked or frustrated the satisfaction of psychological needs. In this situation, materialism and money may be highly valued as a means of self-definition, self-extension, selftransformation and for social communication of power and self-esteem (Prince, 1993; Richins \& Rudmin, 1994). Closely related to this theory, is the human need theory.

\section{The Human Need Theory}

Characterising humans as wanting creatures who perpetually possess some type of unfulfilled need, Maslow (1943:373-384) developed the human need theory which comprises the following human needs:

- $\quad$ Physiological needs - these needs are at the lowest level in the needs hierarchy but their satisfaction is crucial. They include the need for food, water, rest and shelter and other lifesustaining needs. A person will engage in activities of satisfying other needs only when physiological needs are satisfied.

- $\quad$ Safety and security needs - these needs are at the second level in the hierarchy and are a person's need for freedom from physical and psychological harm. When this need is unfulfilled in children, they usually cling to sources of comfort such as a person, favourite toys, and other objects (Oleson, 2004). The preference for routine, familiar things, structure in life, huge savings and various types of insurance, Oleson (2004) reports, are indications for the need for safety and security.

- Love and belongings - These are social needs of companionship, belonging, acceptance, affection which humans will seek to satisfy with great intensity as they would for necessities like food and water.

- $\quad$ Esteem needs - While humans will want to love and be loved, they also have the need and desire for self-esteem, status, and respect from others (Oleson, 2004). Maslow (1943:371-372) classifies esteem needs into two basic categories: (a) the personal desire for adequacy, strength, achievement, confidence, freedom and independence; and (b) the desire for recognition, attention, appreciation, reputation or prestige (respect or esteem from other people). When these needs are satisfied, people feel worthy, adequate, powerful, confident and useful (Oleson, 2004). The reverse will apparently happen when esteem needs are not satisfied. In this case, beliefs may be developed that money and material objects will fill the void.

- Self-actualization needs - At this stage and after the satisfaction of all other needs in the hierarchy, people would develop the need to become fully self-realized and to achieve full potential in what they are best at.

Maslow's human need theory is particularly useful in studying people's motivation, because unlike previous researchers who studied the motivation of people with deficiencies, Maslow examined people without deficiencies (Oleson, 2004). However, it is a rare phenomenon to find people who are psychologically whole because as individuals progressively interact with various environments (for example, the family, school, media, cultures), Maslow (1943) asserts that they develop specific needs which motivate them to respond to their experiences in varied ways.

Iglehart (1971 and 1990) employed Maslow's human need theory to investigate materialism in societies. As Kasser et al. (2002) suggested Iglehart (1990) found that materialistic values are largely derived from a society that failed to satisfy people's physiological and security needs. This deprivation, Iglehart (1990:66) emphasises, may cause people in the society to chronically "focus on lower order needs for material comfort and physical safety over higher order needs such as self-actualization, belonging, aesthetic satisfaction, and quality of life". 
Oleson (2004) equally applied the Maslow's (1943) human need theory to explore the relationship between human needs and money attitudes. He found a strong relationship between money attitudes and both the safety and esteem needs. Consumers who for example, strive to satisfy esteem needs viewed money as a tool of power and may thus engage in symbolic consumption or accumulate material goods to feel socially powerful (Durvasula \& Lysonski, 2010).

\section{The Symbolic Self-completion Theory}

Wicklund and Gollwitzer's (1982) symbolic self-completion theory also emphasises the importance of psychological need satisfaction in materialistic orientations. Materialism according to this theory is fuelled by perceived self-discrepancies (disparity between how an individual sees her/himself (actual self) and how s/he would ideally wish to be (ideal self). Drawing from the symbolic self-completion theory Dittmar et al. (1996) developed a theoretical model of impulse buying that shows that social (for example, gender, age group, social class) and personality (inner/other directedness) factors impact on an individual's self-discrepancies. Self-discrepancies are picked up when people judge their selfworth, a process

Wicklund and Gollwitzer (1982) term as self-definition or description. Individuals who perceive selfdiscrepancies or a sense of incompleteness are motivated to compensate usually with symbolic material possessions such as apparel items.

The self-determination theory, human need theory, and symbolic self-completion theory all points to the fact that if the satisfaction of human needs (either physiological or psychological needs) is perceived to be deficient, individuals will formulate strategies to compensate or to cope with the deprivation. While these theories are valuable in understanding how materialistic values and money attitudes can develop, their explanations according to Moschis (2007) are simplistic, especially as they do not shed light on either the intensity and frequency of deprivation, or do they detect the sensitive periods (age range when deprivation is experienced), within which human needs deprivation may more likely engender money attitudes and materialistic values.

Najman et al. (2010) noted that to get a better understanding of how basic needs deprivation and socioeconomic disadvantages impact on later-life psychological outcomes, the critical or sensitive periods, the effects of the intensity, duration, or frequency of exposure to these experiences should be identified and distinguished. These considerations, Moschis (2007) contends, are some of the merits of the life course approach in understanding consumption orientations.

\section{The Life Course Theory}

Moschis (2007:295) defines the life course paradigm "as a multi-theoretical framework that integrates several approaches used in different disciplines (e.g., sociology, history, developmental psychology and economics) to study consumer behaviour over the course of people's lives". It deals with an understanding of how events that happened at an earlier age or stage in an individual's life affect his/her thoughts and way of behaving later on in life. While the aforementioned theories provide information of the types of experiences or events which are capable of influencing the development of certain values and attitudes, the life course theory adds value by emphasising the importance of recognizing the historic timing of the events, the place (where the events happened), time (duration) or intensity of a child's experience of these events, and the relationship of these events to other stressful events in the child's life (Elder, 1998; Moschis, 2007). The following three theoretical orientations (normative, stress and human capital) guide life course researchers:

\section{(a) The normative perspective}

The normative school of thought works on the premise that certain events (e.g., marriage, divorce, and employment) cause people to transit from one role (e.g., spouse, parent, and employee) to the other in their life course. To enact these roles they need to be socialised with skills and attitudes attuned to social norms. Disruptive family events such as in divorce and discord limit effective parenting (Elder, George \& Shanahan, 1996) which could have (a) imparted basic values, (b) taught children the uses and values of money, (c) imparted consumption values, (d) provided financial means to its dependents and (e) provided emotional support (including love, affection, and intimacy) (Schiffman \& Kanuk, 2004:329 \& 352). Children who grow up receiving inadequate provisions of these basic parental 
resources may have difficulty adapting socially, may develop undesirable consumption values or may end up with low self-esteem which they may later try to assuage by attaching high importance on money and material possessions as a source of power.

\section{(b) The stress perspective}

The stress theory is based on the view that at any given stage or age, people are in a more or less balanced frame of mind until certain events occur. The events, either negative, neutral or positive, not only recent but also in the past, are considered as stressors (causes of disequilibrium). Stressful transitions motivate people to adopt coping mechanisms like materialism (Burroughs \& Rinfleisch, 1997).

Rindfleisch et al. (1997); Hill, Yeung and Duncan (2001) and Roberts, et al. (2006) interpret the stress theory from the perspective of disrupted family structure such as divorce and separation. Divorce is accompanied by stressful events such as role reorganizations, movements, a diminished nurturing and parental care received by children. Children living in economically deprived single-parent families McLanahan and Booth (1989) emphasise, often assume adults' tasks of earning money for the family or taking care of younger siblings. Individuals who face these stressful childhood family life changes often develop compensatory consumption behaviour like materialism (Burroughs \& Rinfleisch, 1997).

\section{(C) Human capital perspective}

With this perspective, human capital (e.g., resources, qualifications, skills, and knowledge) accumulation is seen as a life course process that begins from early life. The concern of life course researchers is to identify salient life events and roles that act as sources of human capital growth or decline and are likely to bring about changes in patterns of thought and action (Frytak, Harley, \& Finch, 2003; Moschis, 2007). The family according to Frytak, et al. (2003) is a source of human capital. A reduction in financial resources due to parental divorce adversely affects children's accumulation of human capital such as the educational attainment necessary for achieving higher occupational status and wealth (Moschis, 2007).

Conceptualizing the human capital perspective in terms of the Economic Hardship Theory, Hill el al. (2001) point out that, mother-only families tend to have lower incomes than two-parent families. Inequalities in family resources Rindfleisch et al. (1997) report, place children from such disrupted families at an inherent disadvantage compared with children in intact families. This may affect their life chances and self-esteem, and thus encourage them to place a high degree of importance on financial security and on material possessions that symbolize success and status later in adulthood.

Realizing that the life course theoretical perspectives can be useful in explaining consumption orientations, Rindfleisch et al. (1997) applied some of the perspectives to develop a model of the relationships between family structure and both materialism and compulsive buying. Their model showed that family resources (tangible and intangible) and family stressors (role reorganizations, diminishing nurture and parental care) can mediate how family structure experienced before the $18^{\text {th }}$ birthday influence materialism and compulsive buying later in life. It also shows the potential of socioeconomic status (SES) to moderate the impact of family structure on both family resources and family stressors.

\section{The Proposed Framework and its essence}

The empirical testing of Rindfleisch et al. (1997) life course model of materialism and compulsive buying by various researchers revealed that:

- Disruptive family structures do influence the development of materialistic values and compulsive buying behavior (Rindfleisch et al., 1997 and Roberts et al., 2003 and 2006). Both teenagers in Roberts et al. (2003) study and young adults in Rindfleisch et al. (1997) study who were materialistic used the purchase and enjoyment of material goods as a coping mechanism against insecurity caused by divorce or separation. If divorce produced insecurities, could it not have first affected money attitudes, especially considering Hanley and Wilheim's (1992) findings that compulsive spenders hold symbolic attitudes (obsession and power/prestige) towards money, because they believe in its ability to enhance self-esteem? 
- Rindfleisch et al. (1997) and Roberts et al. (2003) studies also revealed that there was no moderating effect of socio-economic status on the family structure-family resources/stressors relationships. This implies that irrespective of a family's pre-divorce socio-economic status, subjects still perceived divorce as stressful and family resources (especially the intangible resources of love and emotional support) as inadequate.

- In terms of the relationship between both family resources and stressors and materialism, Rindfleisch et al. (1997) found that only the absence of intangible family resources have a bearing on subjects' reliance on the happiness dimension of materialism. Roberts et al. (2003) findings indicated that family stressors were rather the main causes of happiness materialism. What role has money attitudes on these relationships? Cross-culturally, the life course studies of materialistic values have produced mixed results. While Rindfleish et al. (1997 and Roberts et al. (2003) found a relationship between childhood family structure and materialism in the U.S., Flouri (1999) in the U.K and Benmoyal-Bouzaglo and Moschis (2010) in France did not find any relationship. Nguyen, Moschis \& Shannon (2009) in Thailand found that childhood disruptive family structure influenced materialism only among Thai young adults from lower social classes. This is in contrast to Rindfleisch et al. (1997) and Roberts et al. (2003) studies which found no moderating effect of SES. Can differing money attitudes and cultural differences account for these mixed results?

All of the researchers who adopted the life course approach to study materialistic values did not investigate the moderating role of money attitudes; neither did they assess the impact of childhood family experiences on money attitudes.

Richins and Rudmin (1994) posit that people low and high in materialism may differ in the meaning and values they attach to money. Mitchell and Mickel (1999) also report that, people who value money highly also have high need for achievement and may score higher in materialism. The meaning people attach to money Mitchell and Mickel (1999) contend is partly determined by their early childhood experiences, even though no empirical proof was provided. The concerns raised in the findings above and the fact that in most behavioural intentions and action, Mitchell and Mickel (1999) stress that money attitudes are always active in the background, it is therefore necessary to include the moderating role of money attitudes in the life course study of materialism. The proposed framework is depicted in Figure 1. 
Figure 1: The proposed framework
Antecedents
Processes
Outcomes

\section{Childhood Family Experiences}

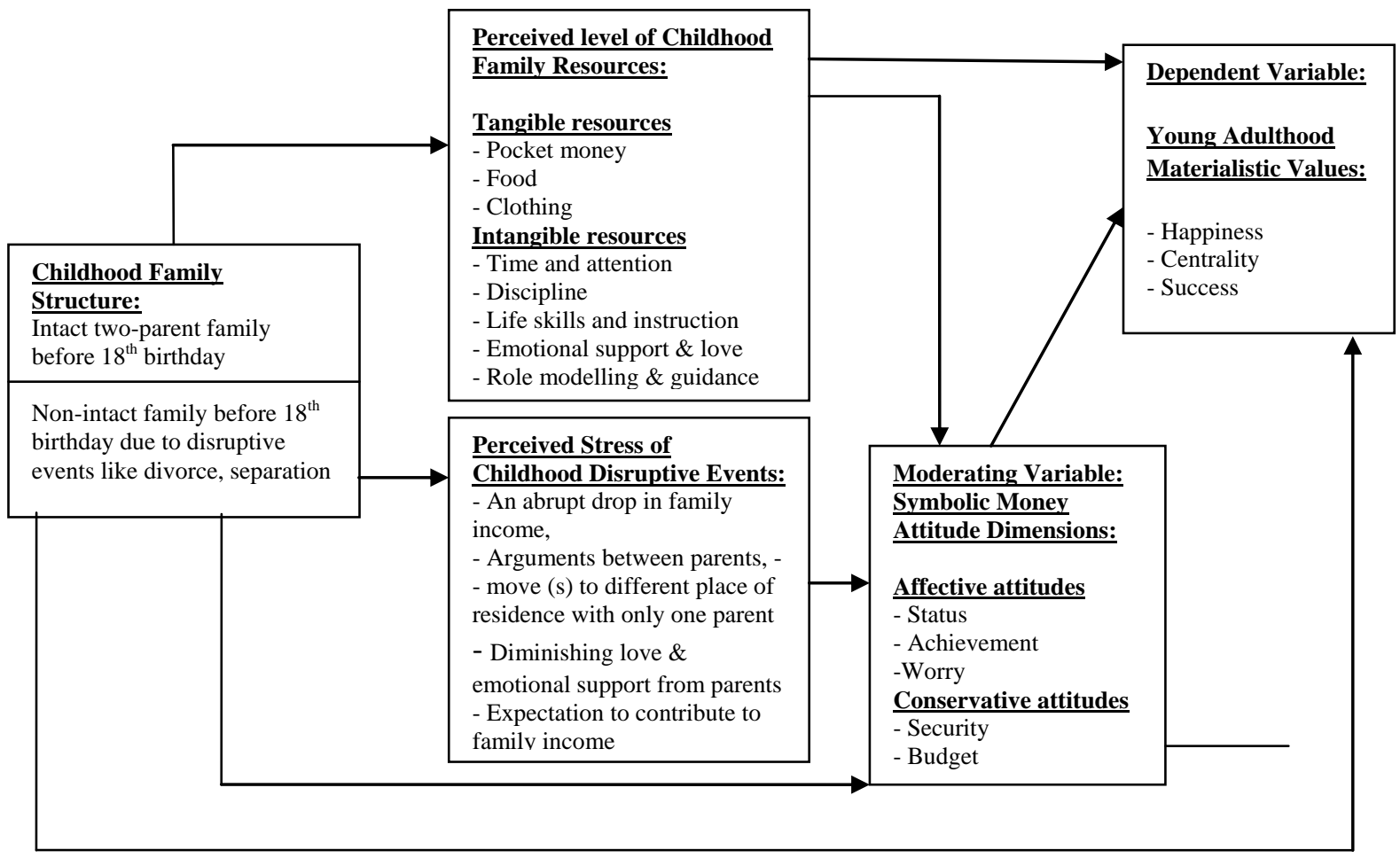

Figure 1 shows that depending on whether an individual grew up in an intact (two parent household) or a non-intact (disruptive situations emanating from parental divorce or separation) family before his/her $18^{\text {th }}$ birthday, family resources (tangible and intangible) may be considered inadequate or stress may be perceived to be more. The perceived stress and level of family resources will either affect the development of materialistic values directly or indirectly through how they shape money attitudes. In addition, growing up in an intact or non-intact family structure is also seen as having a direct influence on materialism or indirectly through its effect on money attitudes.

\section{THE VARIABLES OF THE PROPOSED FRAMEWORK}

\section{Childhood Family Structure}

Even though children experience varied (for example, 'two-parent family', 'mother-only family', 'mother-with-stepfather family', 'mother-with-grandparent(s) family' - Hill et al., 2001:273) family structures when they are growing up, Rindfleish et al. (1997) categorize these experiences into mainly two types namely "intact" and "non-intact" family structures. They define the "non-intact" or disruptive family structure as "the dissolution of a two-parent family due to divorce or separation (Rindfleish et al., 1997:312) unlike the "intact" that represent the 'two-parent family' (Hill et al., 2001).

Family structure for this proposed framework is viewed in terms of whether it is "intact" and "nonintact". It should be measured in terms of whether respondents did or did not live with both their biological parents before their $18^{\text {th }}$ birthday respectively (Rindfleish et al., 1997; Roberts et al., 2003), because life course researchers report that family disruptions experienced when subjects are adolescence (13-18 years old) are more impactful on later behaviours (Chase-Lansdale, Cherlin \& Kierman, 1995; Elder, 1998; Hill et al., 2001). 


\section{Perceived Level of Childhood Family Resources}

Rindfleisch et al. (1997) classify and measure family resources in terms of tangible (pocket money, food, and clothing) and intangible resources such as adult supervision, practical help, love, emotional support, role modelling and guidance. Similarly, this proposed framework suggests that the perceived level of childhood family resources, take Rindfleisch et al. (1997) ratings of the tangible and intangible family resources.

\section{Childhood Perceived Stress from Disruptive Family Events}

Children, who experienced family disruptions such as divorce, often also face a number of other stressful events like parental conflict, movement to different locations, change of caregivers, diminishing love and emotional support and role changes (Hill et al., 2001; Rindfleish et al., 1997). In addition to these stressful events, researchers using this framework can include country-specific stressful events.

\section{Symbolic Money Attitude Dimensions}

Money attitudes for this proposed framework are defined as "the meanings, importance, feelings, values and beliefs an individual or a group of individuals attach to money, which guide their moneyrelated behaviours". This definition stems from researchers findings that money takes on a number of emotional and attitudinal meanings including respect, power, achievement, anxiety, status, love and security (Furnham 1984; Goldberg \& Lewis, 1978; Rose \& Orr, 2008; Yamauchi \& Templer, 1982). Mitchell and Mickel (1999) noted that the meaning people attach to money tends to include more affective and symbolic components than the rational or conservative meaning.

\section{Materialistic Values}

In line with Richins and Dawson's (1992:308) definition of materialism, materialists in this suggested framework should be considered as "consumers who place material possessions and acquisition at the centre of their lives, value possessions as a means of achieving happiness, or use possessions as indicators of success and status", hence the three materialistic values of centrality, happiness and success.

\section{CONTRIBUTION OF THE STUDY}

This study would advance theory and practice in the area of consumer decision-making. Despite reports that money attitudes can influence decision-making, information processing, consumer financial behaviours such as saving, debt, credit card use and exchange relations (Burgess, 2007), there is very limited amount of research in the marketing discipline on money attitudes. To spur research in this area, Durvasula and Lysonki (2010) recommend that a comprehensive model of money attitudes, their antecedents and outcomes like materialistic values be developed. This study fills this gap by developing a conceptual life course framework of materialism that delineates how antecedent of childhood family experiences affect money attitudes and in turn determine the development of materialistic values. If the determinants and outcomes of money attitudes of different consumer segments are examined and revealed, predictions can be made of how they will make financial and consumption decisions.

\section{Practical importance of the study}

There is a clear difference in product preferences between consumers who are materialistic and those who are not. Richins (1994), Holt (1995) and Rindfleisch, Freeman and Burroughs (2000) for example, investigated the possessions that are most important to those high in materialism. They found that high materialists love high status, costly and publicly visible possessions unlike low materialists who cherish possessions that carry remembrances of relationships. Specifically, Rindfleisch et al (2000) found that high materialists are attracted to cars with luxury image (e.g., Lexus) than those with a nostalgic image (e.g., the new VW Beetle). 
Benmoyal-Bouzaglo and Moschis (2010) also report that materialistic as opposed to non-materialistic consumers are attracted to products and appeals that emphasise public acceptance and status. An examination of how childhood family experiences influence money attitudes and materialism can provide an explanation of these phenomena and give marketers ideas of how to position their offerings. For example, marketers can place emphases on products' symbolism, security, popularity, and prestige depending on what money attitudes and materialistic values the consumers will exhibit.

\section{SUGGESTIONS FOR FURTHER RESEARCH}

The realization that the life course approach is useful in understanding consumption orientations has created the essence to develop appropriate framework with which to test how early-life family experiences affect the development of some consumption values and attitudes. Rindfleish et al. (1997) and Moschis (2007) life course model of consumption orientations has been empirical tested and they produced mixed results. The framework presented in this paper suggests that differing money attitudes as moderators can account for the mixed results.

Further research is needed to test this framework and show evidence for the hypothesized relationships. Confirmatory factor analyses can be conducted to extract and validate the distinct dimensions of money attitudes and materialistic values authors have found. T-tests can be used to test differences in money attitudes and materialistic values among subjects reared in intact and disrupted families. The predictive power of the independent variables (perceived family resources, stress and money attitudes) of materialism (dependent variable) can be assessed using correlations or multiple regression analyses.

The moderating effect of each of the money attitude dimensions can be tested by employing hierarchical regression analysis (HRA). HRA, Rindfleisch et al. (1997) explain, is the most appropriate statistical test for examining moderators. With the HRA, the independent variables are first meancentred; individual predictors are entered, followed by the product term (the independent variable multiplied by the moderating variable). A moderating effect is confirmed by the presence of a significant two-way interaction (Rindfleisch et al., 1997).

\section{CONCLUSION}

The review and assessment of literature on theories that provide explanations of how money attitudes and materialistic values can develop revealed that Ryan and Deci's (2000) self-determination theory, Maslow's (1943) human need theory, Wicklund and Gollwitzer's (1982) symbolic self-completion theory and the life course theory provide useful insights. Of these theories the life course theory was found more innovative because they provide multidisciplinary explanations, takes into account the timing, the duration and intensity of the experiences that may affect money attitudes and materialism. The life course theoretical perspectives were therefore employed to conceptualize this study's framework. The framework proposes that the degree to which the perceived family resources and stress of children reared in non-intact/intact homes influence their materialistic values depends on the money attitudes they eventually adopt. Marketers and academics can use this framework to empirically test and understand the money attitudes and materialism dynamics of various consumer segments.

\section{REFERENCES}

Benmoyal-Bouzaglo, S., \& Moschis, G. P. (2010). Effects of family structure and socialization on materialism: a life course study in France, Journal of Marketing Theory and Practice, 18 (1), pp. 55-71.

Burgess, S. M. (2007). Toward a theory on the content and structure of money attitudes, Advances in Consumer Research, 32, pp. 682-683. 
Chase-Lansdale, P. L., Cherlin, A. J., \& Kierman, K. E. (1995). The long-term effects of parental divorce on mental health of young adults: a developmental perspective, Child Development, 66, pp. 1614-1634.

Dittmar, H., Beattie, J., \& Friese, S., (1996). Objects, decision considerations and self-image on men's and women's impulse purchases, Acta Psychologica, 93, pp.187-206

Durvasula, S.,\& Lysonski, S. (2010). Money, money, money - how do attitudes toward money impact vanity and materialism? The case of young Chinese consumers, Journal of Consumer Marketing, 27 (2), pp. 169-179.

Elder, G. H., Jr. (1998). The life course as developmental theory, Child Development, 69(1), pp. 1-12

Elder, G. H. J., George, L. K. \& Shanahan, M. J. (1996). Psychosocial stress over the life course. In Psychosocial Stress: Perspectives on Structure, Theory, Life Course, and Methods (ed. by H.B. Kaplan), Academic Press, Orlando, FL. pp. 247-292.

Flouri, E. (1999). An integrated model of consumer materialism: Can economic socialization and maternal values predict materialistic attitudes in adolescents? Journal of Socio-Economics, 28, pp. 707-724.

Frytak, J., Harley, C.R. \& Finch, M.D. (2003). Socioeconomic status and health over the life course. In Handbook of the Life Course (ed. By H.T. Mortimer \& M.J. Shanahan), Plenum Publishers, New York, pp. 623-643.

Furnham, A. (1984). Many sides of the coin: The psychology of money usage, Personal and Individual Differences, 5, pp. 501-509.

Goldberg, H., \& Lewis, L. (1978). Money madness: The psychology of saving, spending, loving, and having money. London: Springwood.

Gurney, K. (1988). Your money personality. New York: Doubleday.

Hanley, A., \& Wilheim, M. S. (1992). Compulsive buying: An exploration into self-esteem and money attitudes, Journal of Economic Psychology, 13, pp. 5-18

Hill, M.S., Yeung, W-J. J., \& Duncan, G.J. (2001). Childhood family structure and young adult behaviours, Journal of Population Economics, 14, pp. 271-299.

Holt, D. (1995). How Consumers Consume: A Typology of Consumption Practices, Journal of Consumer Research, 22(1), pp. 1-16.

Iglehart, R. (1971). The Silent Revolution in Europe: Intergenerational change in post-industrial societies, American Political Science Review, 65, pp. 991-1017.

Iglehart, R. (1990). Culture shift in advanced industrial society, Princeton, NJ: Princeton University Press.

Kasser, T., Koestner, R., \& Lekes, N. (2002). Early family experiences and adult values: A 26-year prospective longitudinal study, Personality and Social Psychological Bulletin, 28, 826-835.

Maslow, A. H. (1943). A theory of human motivation, Psychological Review, 50, pp. 370-396.

Mitchell, T. R., \& Mickel, A. E. (1999). The meaning of money: An individual difference perspective, Academy of Management Review, 24 (3), pp. 568-578. 
Moschis, G. P. (2007). Life course perspectives on consumer behaviour, Journal of the Academy of Marketing Science, 35 (2), pp. 295-307.

Najman, J. M., Hayatbakhsh, M. R., Clavarino, A., Bor, W., O'Callaghan, M. J., \& Williams. G. M. (2010). Family poverty over the early life course and recurrent adolescent and young adult anxiety and depression: A longitudinal study, American Journal of Public Health, 100 (9), pp. 1719-1723.

Nguyen, H. V., Moschis, G. P., \& Shannon, R (2009). Effects of family structure and socialization on materialism: a life course study in Thailand, International Journal of Consumer Studies, 33 (4), pp. 486-495.

Oleson, M. (2004). Exploring the relationship between money attitudes and Maslow's hierarchy of needs, International Journal of Consumer Studies, 28 (1) pp. 83-92.

Prince, M. (1993). Self-concept, money beliefs and values, Journal of Economic Psychology, 14, pp. 161-173.

Richins, M. L. (1994). Special Possessions and the Expression of Material Values, Journal of Consumer Research, 21, pp. 522-533.

Richins, M. L., \& Dawson, S. (1992). A consumer values orientation for materialism and its measurement: scale development and validation, Journal of Consumer Research, 19 (4), pp. 303-316.

Richins, M. L., \& Rudmin, F. W. (1994). Materialism and economic psychology, Journal of Economic Psychology, 15, pp. 217-231.

Rindfleisch, A., Burroughs, J. E., \& Denton, F. (1997). Family structure, materialism and compulsive consumption, Journal of Consumer Research, 23 (4), pp. 312-325.

Rindfleisch, A., Freeman, D. \& Burroughs, J. E. (2000). Nostalgia, Materialism, and Product Preference: An initial Inquiry, Advances in Consumer Research, 27, pp. 36-41.

Roberts, J.A., Manolis, C., \& Tanner, J. Jr. (2003). Family structure, materialism and compulsive consumption, Journal of the Academy of Marketing Science, 31(3), pp. 300-311.

Roberts, J.A., Manolis, C., \& Tanner, J. Jr. (2006). Adolescent autonomy and the impact of family structure on materialism and compulsive buying, Journal of Marketing Theory and Practice, 14(4), pp. 301-314

Rose, G. M., \& Orr, L. M. (2007). Measuring and exploring symbolic money meanings, Psychology \& Marketing, 24(9), pp. 743-761.

Ryan, R., \& Deci, E. (2000). Self-determination theory and facilitation of intrinsic motivation, social development, and well-being, American Psychologist, 55, pp. 68-78.

Schiffman, L.G. \& Kanuk, L. L. (2004). Consumer Behaviour, $8^{\text {th }}$ edition, Pearson Prentice-Hall. Pearson Education International.

Ward, S. (1974). Consumer socialization, Journal of Consumer Research, 1, pp. 1-14

Watson, J. J. (2003). The relationship of materialism to spending tendencies, saving, and debt, Journal of Economic Psychology, 24, pp. 723-739.

Wicklund, R. A., \& Gollwitzer, D. (1982). Symbolic self-completion. Hillsdale, NJ: Erlbaum 
E Mazibuko

Yamauchi, K., Templer, D. (1982). The development of a money attitude scale, Journal of Personality Assessment, 46, pp. 522-528. 